\title{
The Absence of Generosity and Obedience to Authority: Judgments of Teachers and Students From Kindergarten ${ }^{1}$
}

\author{
Rosana Akemi Kawashima \\ Universidade Estadual Paulista \\ “Júlio de Mesquita Filho”, São José \\ do Rio Preto-SP, Brazil
}

\author{
Raul Aragão Martins ${ }^{2}$ \\ Universidade Estadual Paulista \\ “Júlio de Mesquita Filho”, São José \\ do Rio Preto-SP, Brazil
}

\begin{abstract}
Preschool Education can provide conditions for the construction of moral values in children. This study's objective was to investigate the judgment of teachers and students in Primary Education regarding the virtue of generosity and whether, in this judgment, it is valued more than obedience to authority. Interviews were held with 26 teachers and 90 children from four municipal schools, using a stimulus-story about an activity using modeling clay. The results indicated that, for the majority of participants, the attitude of the teacher in the stimulus-story, in not helping the child and demanding obedience in first place, is wrong. In relation to the reasons, for the majority of the teachers, the lack of help is justified because the activity with the modeling clay should be free, prioritizing the child's wishes. For the majority of the children, however, the teachers' lack of help is felt as failure to attribute postive value. Furthermore, it was observed that the strength of the virtue of generosity among the participants in this study is weak.
\end{abstract}

Keywords: generosity, obedience, preschool education, moral development, pre-school educators

\section{Ausência de Generosidade e Obediência à Autoridade: Juízos de Professores e Crianças da Educação Infantil}

\begin{abstract}
Resumo: A Educação Infantil pode proporcionar condições para a construção dos valores morais nas crianças. O objetivo deste estudo foi investigar os juízos de professores e alunos da Educação Infantil em relação à virtude generosidade e se nesse juízo ela é mais valorizada que a obediência à autoridade. Foram entrevistados 26 professores e 90 crianças de quatro escolas municipais, utilizando-se uma estória-estímulo sobre uma atividade com massa de modelar. Os resultados indicaram que, para a maioria dos participantes, é errada a atitude da professora da estória-estímulo em não ajudar a criança e exigir obediência primeiramente. Quanto às justificativas, para a maioria das professoras, a falta de ajuda se justifica porque a atividade de massa de modelar deve ser livre, priorizando a vontade da criança. No entanto, para a maioria das crianças, a falta de ajuda da professora é sentida como falta de atribuição de valor positivo. Além disso, foi constatado que é fraca a força da virtude generosidade entre os participantes desta pesquisa.
\end{abstract}

Palavras-chave: generosidade, obediência, educação infantil, desenvolvimento moral, educadores infantis

\section{La Ausencia de Generosidad y Obediencia a la Autoridad: Juicios de los Profesores y los Niños de Educación Infantil}

\begin{abstract}
Resumen: La Educación Infantil puede proporcionar condiciones para la construcción de los valores morales en los niños. La finalidad de este estudio fue investigar los juicios de los profesores y niños de la Educación Infantil respecto a la virtud de la generosidad y si esta virtud es más valorada que la obediencia. Fueron entrevistados 26 profesores y 90 niños de cuatro escuelas municipales, les presentando una historia-estímulo. Los resultados indican que, para la mayoría de los participantes, la actitud de la profesora es equivocada, además de exigir obediencia primero. Respecto a las justificativas, para la mayoría de las profesoras, la falta de ayuda se justifica porque la actividad debe ser libre, priorizando la voluntad del niño. Sin embargo, para la mayoría de los niños, la falta de ayuda por parte del profesor se percibe como falta de atribución de valor positivo. La fuerza de la virtud generosidad es débil entre los participantes de esta investigación.
\end{abstract}

Palabras clave: generosidad, obediencia, crianza del niño, desarrollo moral, educadores infantiles

\footnotetext{
1 Article derived from the first author's doctoral dissertation, under the supervision of the second, defended in 2013 on the Graduate Program in Education of the Universidade Estadual Paulista "Júlio de Mesquita Filho", Marília campus.

Support: São Paulo Research Foundation - FAPESP (Protocol no. 2009/15685-3) and Fundação de Apoio à Pesquisa e Extensão de São José do Rio Preto - FAPERP (Protocol no. 07/2015).

2 Correspondence address:

Raul Aragão Martins. Departamento de Educação. Rua Cristóvão Colombo, 2265. Bairro Jardim Nazareth. CEP 15054-000. São José do Rio Preto-SP, Brazil. E-mail: raul@ibilce.unesp.br
}

The present-day transformations in society have not occurred only in politics, the arts, the economy, science and education, but also in human relationships, above all regarding moral values. According to La Taille (2009), one of the main transformations in the contemporary world is owed to the difficulty the human being has in coexisting with a range of choices in a world without stable values, in which everything has value today, but, as far as one knows, 
may not tomorrow. Consequently, contemporary man seeks immediate pleasure and satisfaction, and annuls is any possibility of choice, as choosing and opting for some things means leaving others to one side; therefore, he does not become attached to and does not value the world around him.

La Taille and Menin (2009), disturbed by contemporary moral questions, suggest that moral values are passing through a process of transformation, change and even depending on the case - of questioning the values present in contemporary society. Pedro-Silva (2010) evidenced that currently there are not only variations in how moral values are being experienced, but also changes in the attitude of authority (some speak of a crisis of authority), as much in the family ambit as in the school ambit. For the author, these transformations have led the individuals to no longer know which rules to follow and neither to be able to guarantee social and individual harmony. Faced with this scenario, in the family, the parents feel lost and, thus, transfer the upbringing of their children to institutions, such as, for example, the school. In school, the teachers are also confused, as punishments - previously permitted - are no longer accepted, and when applied, no longer seem to have the same effect as before, as, in the presence of psychological, pediatric and pedagogical knowledge, and knowledge from the mass media, the parents and educators either do not know what course to follow, or show pessimism regarding its efficacy (Pedro-Silva, 2010).

As a result, in order to understand the attitudes of authority, it is essential to address how authority is constituted in the social relationships. However, La Taille (1999) warns that analyzing authority relationships is very difficult and even risky, as, on the one hand, it relates to power relationships, these relationships being derived from the political, economic and cultural spheres; while, on the other, as a result of being an issue of power relationships, authority can be constituted on illegitimate bases which lead to authoritarianism and injustice. Both are found in the field of education. The question of authority, therefore, can be reflected in two aspects: one linked to the use of strength or violence, in the case of authoritarianism, and the other to how authority must be in the school, linked not to the use of strength and violence, but rather to the admiration and prestige of the person who demonstrates possessing competence in a specific matter (Araújo, 1999).

This relationship of authority is very delicate, as the teacher has to wish to teach somebody something, who may not want to be taught and, at the same time, she needs to establish a hierarchy; not an uncontrolled hierarchy, in which one orders and the other obeys. It is necessary for the teacher, taking a superior position, as a master, to establish a pact delimiting each one's functions and places. In parallel, the teacher too must not forget to follow these same rules (Aquino, 1999).

In this case, for the teacher to act with authority in the classroom, she needs first of all to be respected by her students. Piaget (1932/1994) postulated two types of respect between people, unilateral respect and mutual respect. In unilateral respect, the morality of obedience and authority rules, while in mutual respect, the moral of reciprocity and cooperation predominates. In Preschool Education, the relationship between the child and the adult, if there is respect, the respect for authority has primacy, and this authority needs to act such that all the affective, intellectual, moral, physical and nutritional dimensions, among others, should be covered as its objective. However, for the Preschool Education teacher to educate and exercise her authority efficaciously, her functions need to be well-defined, as the first figures of institutionalized authority with which the children coexist are found in the school (Machado Junior, 2009).

Initially, Preschool Education belonged to the area of social work, in which in principle the attendance to early childhood in Brazil sought to "compensate for shortcomings": nutritional, sanitary, affective and social shortcomings. It was only after the 1988 Constitution that attendance for children from birth onwards was established as a right of children and the duty of the State. Two years later, in 1990, the Statute of the Child and Adolescent (ECA) reiterated the child's right to citizenship, defining her rights to protection and education. Based on the promulgation of the ECA, seeking the qualification of the attendance to the small child, the Law of Directives and Bases of National Education (1996) guaranteed the incorporation of children's education from zero to six years of age in the Brazilian teaching system, defining it as the first stage of Basic Education. In the light of these occurrences, in 2006, the Ministry of Education coordinated the elaboration of the National Policy for Early Childhood Education document, which defines, among other objectives, the strengthening of the conception of education and care as aspects which cannot be dissociated from the actions directed towards the children. However, following laws which regulate and define the integrated functions of caring and educating, that is often seen as impregnated with beliefs and prejudices, culminating in the fragmentation and disqualification of the care in attending the small child (Campos, Esposito, Bhering, Gimenes, \& Abuchaim, 2011; Freitas \& Shelton, 2005; Paschoal \& Machado, 2009; Sayão, 2010).

The valuing of the act of caring has been the objective of many researchers, and it was finally, with Montenegro (2005), that caring was reconceptualized in a higher form. The author investigated and brought together different concepts regarding care in Preschool Education and, after examining the different feelings and meanings given to the word in the literature, the author faced the concept of care linked to ethics, which postulates respect for people as the base of any relationship of care, introducing morality. Thus, Montenegro associated the care with the moral field, relating it to generosity and, in this way, enhanced the meaning of the word 'care' as one among the moral virtues. Therefore, the virtue of generosity reflects what academics of the area 
have sought: the indissociability of caring and educating in Preschool Education.

In the light of this, what is the meaning of morality and ethics, and what is moral value? For La Taille (2006b, 2010), La Taille, Justo and Silva (2010), Tognetta (2009a, 2009b) and Tognetta and Vinha (2009), among others, morality represents a set of rules which allows the subjects to think about how they must act for the well-being of others, and that, in this action, the content is moral values. Ethics represents wanting to do good to the other and to feel good in this action. The moral values are desirable qualities to do what is good for oneself and for others, and these are related to a person's character.

There is a consensus among academics that the most important moral value is justice, as a result of which this has been the virtue studied most in Moral Psychology, as Piaget did (1932/1994). In the present study, the virtue of generosity was considered, and the reasons will be explained below.

The first argument for the choice of the virtue of generosity is due to the fact that caring is one of the main functions of the teacher in Preschool Education. Belonging to the moral field, it becomes a noble function for the teacher who works with the small child. In addition to this, generosity covers the function of caring and educating, making possible the juxtaposition between intelligence and affectivity as, in order to be generous, it is necessary to feel sympathy for a person, decentration being necessary in order to be able to evaluate (think, reason) whether the person deserves this feeling (of sympathy) and, thus, to act generously.

We see in La Taille (2000) what he has to say. The author took a phrase from Piaget's book "The Moral Judgment of the Child" (1932/1994), that: “... it is when the child is accustomed to act from the point of view of those around him, when he tries to please rather than to obey, that he will judge in terms of intention" (p. 105, italics by La Taille). For La Taille (2000), this phrase, as well as explaining the process of passing from heteronomous morality to autonomous morality, speaks more of generosity than justice, when Piaget used the verb "to please", therefore, La Taille raised the hypothesis that generosity precedes justice, morally speaking, from the chronological point of view. Later, in 2006, La Taille undertook a study in order to ascertain the genesis of generosity in morality and concluded that "[...] generosity is not only a virtue present in the beginning of the genesis of morality, but is better assimilated and, therefore, integrated into moral consciousness, than justice in this same phase of development" (La Taille, 2006a, p. 16). This reinforces the second argument, that the generosity of the teacher in Preschool Education must be taken into account, showing that this virtue can be perceived in the relationship of authority with the children and between them as well.

But what is generosity? In the words of La Taille (2006b, p. 62), "the act of generosity favors who is contemplated by it, not who acts generously. It is because generosity is entire dedication to the other that I say that it fully translates altruism". And, furthermore, "in generosity, one gives to the other not what is his by right, but rather what corresponds to a unique need" (La Taille, 2006a, p. 10). It is what is in play in generosity, and what differentiates it from justice.

For La Taille (2006b), the feeling of sympathy is the basis for generosity. The author defined this feeling as the ability to feel what the other feels, not simply the other's pain, but also the other's needs. For Piaget (1954), sympathy is a feeling based in judgments of mutual value between the individuals, and occurs through a perceptual contact. This contact occurs when, in the affective experience, the child has pleasure in identifying things which please her, in the perspective of the organs of feeling. These perceptive emotions can be defined as the child's link with the experience which she lives through in that moment, a point in which her organs of feeling and her motor actions are important references for the construction of future moral feelings. As a result, if there is perceptive emotion, there is something which pleases the body and the thinking, and thus, one learns to identify information or qualities in the things or in we ourselves and comes to recognize pleasant and unpleasant things. Now, for morality to be constituted, it presupposes, besides other things, that the other, similar to it, should be perceived, that is, that people, objects or ideas have value: thus, sympathy would participate in the bases of the mutual valorizations which lead the child to mutual respect.

If one considers along with Montenegro (2005) that generosity enriches the field of moral education and that it is part of the role of the teacher of Preschool Education, it seems relevant to study whether this virtue belongs to the moral universe of the educators, and whether it is recognized by the children in their teachers. As, according to Piaget $(1932 / 1994)$, in the relationship with the small child, the teacher is heteronomous, it is believed that it is the objective of all who educate to make the child overcome this tendency and reach an autonomous morality, which entails shaping ethical citizens, prepared for life in society and capable of thinking critically. This aspect is emphasized in the National Curriculum Parameters (PCN) (Ministry of Education and Sports, 1997) and in the National Curricular Reference for Child Education (RCNEI) (Ministry of Education and Sports, 1998), which calls for ethics as a "transversal theme" to be worked upon in the school.

As a result, the role designated to generosity in the relationship between the teacher and the child in Preschool Education is clear. For there to be generosity in this relationship, it is necessary for there to be a commitment on the part of the teacher toward the child in all her aspects. The teacher needs to understand what the child feels and thinks, what she brings with her, her history and her wishes. Thus, as the virtue of generosity needs involvement with the other, this means that the teacher needs to have the conditions to give attention to the children's needs, including emotional, 
bodily, intellectual, moral and hygiene needs, respecting the individual differences, in the search for comprehensive and healthy development.

Based on these reflections, therefore, this study's objective was to investigate the judgments of teachers and students of Preschool Education in relation to the virtue of generosity, and whether, in this judgment, it is valued more highly than obedience to authority.

\section{Method}

\section{Participants}

The study participants are teachers and students of Preschool Education from four municipal schools in a medium-sized city in the non-metropolitan region of the State of São Paulo. The children selected are those who obtained authorization from those responsible for them to participate in the study, and were aged between four and six years old; as a result, the group studied was made up of 90 children, 30 children of each age, divided equally by sex. The teachers in this study are those who teach for the four schools selected, and who accepted to participate in the study, corresponding to the number of 26 participants.

One observation is necessary in relation to the "first year", the school year considered as Elementary School, but placed by us as belonging to Preschool Education. At the time of the first contacts with the school sent with the Department of Education, the "first year" was still considered as the old preschool, which was named by some schools as the first year of elementary school. At the time of moving up a school year and, therefore, at the beginning of data collection, the term used changed in all the schools, but they continued to be taught in Preschool Education schools, as when they opted to remain in rooms of the "first year", they were considered as mixed schools: preschool and elementary. At that time, we termed our subjects as belonging to Preschool Education, as they themselves still considered themselves to belong to this nucleus (Law no. 11,274, 2006).

The characteristics of the teachers studied, firstly by age, reveal that $36 \%$ are aged between 20 and 29 years old, $28 \%$ between 30 and 39 years old, $28 \%$ from 14 to 49 years old, $4 \%$ from 50 to 59 years old, and $4 \%$ are aged over 60 years old. In relation to the time of service, $26.9 \%$ of them have worked for between one and five years as teachers, $3.9 \%$ for between six and 10 years, $26.9 \%$ from 11 to 15 years, $15.4 \%$ from 16 to 20 years, and $26.9 \%$ for over 21 years in teaching. By type of contract, $57.7 \%$ of the teachers are contracted on permanent contracts and $42.3 \%$ are temporary. It was observed that the majority of them began their career through the Mid-Level course in Teaching, totaling 22 teachers, and many of them had worked for more than 15 years as teachers. Of these 22 teachers who began teaching with the Mid-Level course in Teaching, nine had completed the undergraduate course in Pedagogy and three had undertaken a specialization course.

\section{Instruments}

The clinical Piagetian interview was used as the data collection method (Delval, 2002; Piaget, 1926/1975, 1932/1994). As the instrument, a stimulus-story was administered, to both the groups, teachers and children, it being the case that for the children it was necessary to construct pictures, a resource used mainly with small children (Martins, 1986). Each participant judges the action of the teacher who did not help the student. The stimulusstory is presented below, followed by the question posed:

Carlos (Carla) was a student from the class next door and his (her) teacher also gave an activity with modeling clay. The teacher asked everybody to do a dog, but Carlos (Carla) did not want to do a dog, he/ she wanted to make a car (flower). The teacher said that because he/she did not obey her, she wouldn't give any help. The car (flower) turned out kind of twisted. Did the teacher (who did not help) do the right or the wrong thing? Why?

\section{Procedure}

Data collection. Data collection was begun immediately following the signing of the terms of consent by the teachers and by the parents and/or guardians of the children. The interviews were individual, recorded, and were subsequently transcribed.

Data analysis. The transcribed interviews were read, so as to categorize the data for subsequent analysis. These categories underwent three processes: firstly, the categories were listed according to the meaning of each response and, following that, these categories were grouped through corresponding to the same analysis group, in accordance with Delval (2002). Finally, the participants' responses were analyzed by a judge who also categorized them and they were paired with the researcher's categories for reliability of the same. Once the categorization of the data from the interview was concluded, these were initially entered into an electronic spreadsheet and exported to a statistical analysis program (SPSS Statistics, 2011). In this program, calculations were made of the variables' frequencies and percentages. However, quantitative analysis was used as a reference for assisting in presenting and discussing the results, as the qualitative analysis of the same was prioritized.

\section{Ethical Considerations}

The study was approved by the Research Ethics Committee of the Instituto de Biociências, Letras e Ciências Exatas at the Universidade Estadual Paulista "Júlio de Mesquista Filho" (Protocol no. CAAE: 0023.0.229.000-09).

\section{Results and Discussion}

Table 1 presents the responses of the teachers and the children. Generally speaking, the data show that the majority 
of the teachers $(69.2 \%)$ and the majority of the children (87.8\%) considered the teacher's attitude of not helping the child, and demanding obedience in first place, to be wrong. Beginning with the analysis of the reasons provided by the teachers who considered the attitude of the teacher in the story to be wrong, it was revealed that $38.5 \%$ fit in the category "wishes/creativity of the child", arguing that the teacher in the story was wrong in not helping and demanding obedience, because an activity with modeling clay should be free, prioritizing the child's wishes and creativity, and requiring the child to do this activity without help because he or she would not obey meant that the teacher lacked knowledge and flexibility for dealing with the situation. In the category "teacher's obligation", understanding that the teacher was wrong, there were 15.4 percent of answers from the teachers who reasoned that helping is an obligation and a role of the teacher, regardless of whether the child obeyed. And, belonging to the category "care/tenderness for the children", $11.5 \%$ of the teachers considered the teacher's action to be wrong, because helping the child is seen by them as an act of care and tenderness.

Of the children who judged the teacher's attitude to be wrong, $44.4 \%$ were inserted in the category "teacher's obligation", justifying this by saying that the teacher should have helped the child, as it was her obligation as a professional and, also, it is her job to help the child to build beautiful things. Going to the category "child's needs", it was ascertained that $15.6 \%$ of the children justified that the teacher should have helped and perceived the child's need, as she needed the teacher's help to build something beautiful. In addition, 7.8\% thought that the teacher simply did not want to help.

The teachers who considered the attitude of the teacher in the story to be correct (not helping) made up 30.8\% and

Table 1

Frequency and Percentage of the Judgments and Rationales of the Teachers and Children in Relation to Acting in the Absence of Generosity

\begin{tabular}{lcccc}
\hline & \multicolumn{2}{c}{ Teachers } & \multicolumn{2}{c}{ Children } \\
\cline { 2 - 5 } & $f$ & $\%$ & $f$ & $\%$ \\
\hline Judgment & 08 & 30.8 & 11 & 12.2 \\
$\quad$ Considered correct & 18 & 69.2 & 79 & 87.8 \\
Considered wrong & 26 & 100 & 90 & 100 \\
Total & & & & \\
Rationales & 10 & 38.5 & - & - \\
Child's wish/creativity & 08 & 30.8 & - & - \\
Teacher's objective & 04 & 15.4 & 40 & 44.4 \\
Teacher's obligation & 03 & 11.5 & - & - \\
Care/tenderness for the children & - & - & 14 & 15.6 \\
Child's need & - & - & 11 & 12.2 \\
Absence of the child's & & & & \\
obedience & - & - & 07 & 7.8 \\
Teacher doesn't want to help & - & - & 10 & 11.1 \\
Other responses & 01 & 3.8 & 08 & 8.9 \\
Don't know & 26 & 100 & 90 & 100 \\
Total & & &
\end{tabular}

all of their rationales fit in the category "teacher's objective", believing that if the teacher had an objective, the child had to comply, and that she should not have helped. Furthermore, $12.2 \%$ of the children considered that the teacher had been right to demand obedience and not help the child and, of these, within the category "absence of child's obedience", $12.2 \%$ of the children believe that the teacher did not help because the child did not obey. The category of "other responses" covers the responses which do not correspond to the story recounted, or were simply of the "because he did" or "because he didn't type.

In comparing the data relating to the majority of the rationales, both of the teachers and of the students, we ascertained that they are different, that is, the majority of the teachers and children contended the same fact in different ways. According to these teachers, taking the child's creativity into account in a clay modeling activity is more important than demanding obedience; according to the majority of the children, however, the teacher has an obligation to help the child in school activities. Note that the arguments are different but complementary, as even an activity such as clay modeling, which the teachers consider to be exempt from rigor requiring obedience, is seen by the children as an important activity, and, as a result of this, the teacher has an obligation to help them in this construction. According to the National Curricular Reference for Child Education (RCNEI) (Ministry of Education and Sports, 1998), the child's art is considered a spontaneous and selfexpressive manifestation, in which the proposal is free expression and the artistic sensitization of the child. Note that, for some teachers in this study, the disobedience of the child with the modelling clay was shown to be irrelevant, as, for them, the art produced by the child using the modeling clay with freedom and creativity is more important, being in accordance with the proposals of the RCNEI.

However, one can note, within the category "teacher's obligation", understanding that the teacher in the story was wrong, only $15.4 \%$ of the teachers explained that helping is an obligation of the role of the teacher, regardless of whether the child obeyed, while the majority of the children (44.4\%) does not agree with the attitude of the teacher in not helping, as they feel that when the teacher helps, they manage to build beautiful things. Bossolan, Perosa and Padovani (2011) held interviews and an activity involving the resolution of a dilemma with children of six, eight and 10 years old, in order to investigate blood donation as an act of solidarity and were surprised with the children's responses, as they expected smaller children to respond more in favor of authority, reinforcing the existing heteronomous relationship; they obtained, however, results among the majority of the children, even those who were in the preoperative phase (six years old), associating the donating of blood as an act of help, and considered it to be an act of generosity, a precocious value and related to sympathy. It is understood that the children's responses indicate that when 
authority acts without living up to their duties as a teacher and without respecting the rights of the child as a student, who needs the teacher, they do not agree with the authority. This discordance on the part of the child when faced with authority is expressed by the feeling explained by La Taille (2006b) as indignation. For the author, this feeling is awoken when one feels that one's rights/or those of another have been disrespected; for the small child, however, "the deep source of the indignation is the feeling of not being valued" (La Taille, 2006b, p. 127). As a result, it was ascertained that the majority of children take into account the car (flower) turning out twisted, and for this reason, producing a "twisted" work is to consider the child to be worse, compared with a child who produced a work which was not "twisted", that is, for the child, to receive help from the teacher and the car (flower) being beautiful signifies the attribution of affection, and therefore, value. Also according to the academic, "the small child has great difficulty in separating the action from the "being", the criticisms made of what she does are felt as criticisms of what she is" (La Taille, 2006b, p. 128). It is believed that, for these children, making something beautiful will probably please the teacher, which may be accompanied by some praise from the teacher herself and also from the child's class-mates. Therefore, what one observes is that the lack of help from the teacher may signify lack of attribution of value and, as a result, enter into conflict with the authority manifested through the indignation.

It is observed that among those who judged the act of helping the child to be wrong, $11.5 \%$ of the teachers did so based on the rationale of "tenderness/care for the children", and $15.6 \%$ of the children used the rationale of "the child's need". For La Taille (2006b), raising one's awareness to the need of the other and feeling sympathy for the other is one of the ingredients motivating generous actions, a feeling experienced by very young children. What these data show is that few children (and also teachers) are sensitive to the needs of others, results which are in accordance with the research of Vale and Alencar (2012), who ascertained the primacy of obedience to authority over generosity and $60 \%$ of seven-year-old children, and few are the teachers who value care and tenderness and feel sympathy for the other, and therefore, for generous actions.

If on the one hand, there are teachers arguing in favor of freedom of expression using the modeling clay, and because of this considered it to be wrong for the teacher not to help the child, on the other hand, in the category "teacher's objective", there are professionals who defend the strict undertaking of their purposes with modeling clay and, because of this, believe it is correct for the teacher not to help, as the teacher in this story has an objective to achieve through this activity and, if the child did not obey, the teacher should not have helped the child. This other group of teachers believes that if the teacher has a purpose with the modeling clay, this must be followed by the children. According to the RCNEI (Ministry of Health and Sports, 1998), "artistic creation is an exclusive act of the child. It is in artistic activity and in contact with objects of art that a significant part of the knowledge in Visual Arts occurs" (p. 91). It is observed that the attitude of these teachers is not in accordance with the RCNEI regarding either the visual arts or with what Tognetta and Vinha (2007) explained regarding the negotiable and non-negotiable rules. For these researchers, some educators interpret the negotiable rules or the "agreed" in a reductionist and wrong way and evidence that the process of elaborating norms is, often, unfounded. For the authors, the negotiable rules, in which contracts are made ("agreed") and the nonnegotiable rules, rule when strictly necessary and relate to principles of justice, health and safety, for example. It seems that "what was agreed", which the teachers in the present study agree with the children is, actually, establishing an immutable and superior rule, with the agreements, proposals or activities being non-negotiable and must be followed without flexibility. For Tognetta and Vinha (2007), the teachers who print the "agreed" in an imposed way simply institute rules which directly affect their relationship with the children, and obeying their orders is the right thing to do, that is, they are rules which strengthen the unilateral relationship and the child's submission before the adult. It may be that for the teachers in this study, it is very difficult to relinquish the power relationship, no matter how "free" an activity may be, such as one involving modeling clay. For Boto (2010), this relationship of the adults, and requiring obedience at any cost, is owed to the fact that the school teaches the children when it speaks of the world, a world which teaches that obedience is an extremely high value.

It is understood that the teachers must direct the activities and the children requested this attitude from them, as they represent the authority in the classroom, but an activity with modeling clay does not need to be so strict; probably, either through fear of losing authority or through insecurity regarding not complying with the schedule of activities, or even through fear of being reprimanded by the school management, they do not manage to understand the purposes of an activity with modeling clay and act in an authoritarian style, trying to impose an activity, "punishing" the child for not complying with it and, in this way, maintaining and reinforcing the heteronomous and unilateral relationship with the child (Piaget, 1932/1994). It is believed that the adult does not require that all the rules and orders should be obeyed, as her role with authority is to provide an environment which favors the children's autonomy, in which they progressively move beyond the relationship of coercion, and relationships of reciprocity and mutual respect become increasingly frequent.

One should note that $12.2 \%$ of the children considered the behavior of the teacher to be right in demanding the obedience of the child and not helping because she did not obey, as, for them, obeying the teacher is the correct thing to do; therefore, these responses are in accordance with the heteronomous morality of the small children in relation to 
the adults, according to Piaget (1932/1994). However, if the teachers persist in the heteronomous relationship involving the child's submission, it may be that they will have difficulty in establishing reciprocal and egalitarian relationships with their peers, subsequently. Muller and Alencar (2012) investigate how teachers of the 6th to 9th year of basic education judge that they have learnt regarding justice, and how they judge that they teach this value to their students, concluding that the teachers teach how they learn, through impositive and authoritarian actions. Imanishi, Passarelli and La Taille (2011) questioned how present-day young people perceive the adults' morality, these references being moral as much to the children as to the adolescents, and whether there is a split in this judgment between the public and private spheres. These authors obtained, from the young people, negative judgments in relation to the adults, and evaluated positively only those adults from the private sphere, who are invested with emotional warmth, and concluded that the young people do not trust the adults, do not consider them to be ethical people, and question their values.

Generally speaking, both the children and the teachers think that it is wrong to demand obedience as a principle and not to help the child, and the majority of the teachers justify their views by stating that leaving the child to build, without helping her, means liberty and creativity; on the other hand, for the children, not receiving help from the teacher is felt as lack of attribution of value. In the light of this, it is believed that the help from authority for the children represents the construction of a judgment of positive value of themselves, and, feeling oneself to be valued by people who are affectively important and before their peers is a predominant role for the construction of an ethical personality; thus, if the authority values all the children, as well as affording the expansion of themselves, valorizing what they are, it can raise the capacity of the child also to feel valued within her social surroundings.

As a result, the majority of the teachers argues against helping the child, because an activity with modeling clay must be free and creative, and the help for the child is considered by few to be an act of care and tenderness, that is, the capacity to feel sympathy for the other and disposition for generosity. It is perceived, therefore, that the strength of the virtue of generosity among the teachers is weak, however, this virtue is valued by some teachers but, as La Taille explained (2006b), judging it to be necessary is not enough, it is necessary that this should be exercised constantly such that the moral sensitivity of the subject among her peers should be a dimension present in her personality.

On the other hand, the majority of the children explained that the teacher should help the child, as helping the child is an obligation and role of the teacher and this includes helping her to construct beautiful things, and if she does not receive help from the teacher, this act is felt as a lack of attribution of value. However, there are still a few children who perceive the teacher's help with a view to the children's needs. These responses indicate exactly how attentive the children are to the roles, obligations and valorizations of authority, it being the case that initially the child considers what is in accordance with the orders imposed by adult authority to be just and correct, in accordance with Piaget (1932/1994). It seems that our data demonstrate exactly what La Taille (2006b) and Piaget (1932/1994) indicated regarding the child's relationship with authority, in which complying with duty predominates, but it seems that there is something more in this relationship, with feelings observed which form the basis of morality and are part of the construction of morality in early childhood.

Thus, the strength of the virtue of generosity remains weak in the children, but already presents its signs. Nevertheless, if the teachers do not exercise sympathy among the children such that these may act with generosity to their peers and cease to value obedience to authority over generous conducts, there will be persistence of the heteronomous relationship involving the child's submission, and it may be that they will subsequently have difficulties in establishing reciprocal, autonomous and sympathetic relationships with their peers. Moreover, if the adult demands that all her rules and orders should be obeyed, her role as an authority, which is to afford an environment which favors the children's autonomy, will wither away in favor of the heteronomous morality and the relationship of coercion, and the relationships of reciprocity and mutual respect will not be able to develop.

Summarizing, this study's results revealed that more importance should be given to the virtue of generosity, principally in Preschool Education by the teachers, as the children already present signs for this virtue. We believe that generosity in Preschool Education is important, as through this, the small children can learn from an early age and relate more affably with their peers and - who knows contribute such that in coming years, in primary and junior education, the cases of bullying, for example, may be less recurrent among the students. If the capacity for the wellbeing of the other is exercised and encouraged constantly by authority, the child can develop moral sensitivity and care for people and concern herself with peoples' quality of life and, therefore, this will be one of the aspects present in her ethical personality.

In this way, it is anticipated that these results may contribute to outline the profile of the professional who is wished for, as this needs to aim for more than a clean, safe place and to teach the child to read and write. The Preschool Education professional, through the virtue of generosity, may be capable of perceiving the hidden needs of the small child who, often, does not manage to express her wishes and difficulties with clarity. As the authority in the classroom, it is believed that, through the act of caring permeated by the virtue of generosity, the teacher will help the child to develop moral, social and intellectual feelings regarding the others, as well as for herself in search for her autonomy and a place in the world. 
The broadening and deepening of the issue investigated is considered, and it is proposed that other, or more, elements regarding the topic should be researched, as, for example: the manifestation of the feeling of sympathy in children without the weight of authority; the exercising of generosity between peers, both among the children and among the teachers; the evaluating of generosity placed side-by-side with other virtues, such as love and solidarity; among others. Finally, as a negative result, emphasis is placed on the obedience to authority as a value within the school. However, this study's findings bring data from one specific group in the non-metropolitan region of the State of São Paulo, whose reflections may not apply to the groups from other regions of the country, with a different stimulus-story. However, the discussion presented here shows the importance of the moral training of those educators who gave little value to the virtue of generosity, a virtue present in the beginning of the genesis of morality, and which is better assimilated by little children.

\section{References}

Aquino, J. G. (1999). Autoridade docente, autonomia discente: Uma equação possível e necessária. In J. G. Aquino (Org.), Autoridade e autonomia na escola: Alternativas teóricas e práticas (4th ed., pp. 131-153). São Paulo, SP: Summus.

Araújo, U. F. (1999). Respeito e autoridade na escola. In J. G. Aquino (Org.), Autoridade e autonomia na escola: Alternativas teóricas e práticas (4th ed., pp. 31-48). São Paulo, SP: Summus.

Bossolan, R. P., Perosa, G. B., \& Padovani, C. R. (2011). A doação de sangue sob a ótica de escolares: Concepções e valores. Psicologia: Reflexão e Crítica, 24(3), 495-503. doi:10.1590/S0102-79722011000300010

Boto, C. (2010). A racionalidade escolar como processo civilizador: A moral que captura almas. Revista Portuguesa de Educação, 23(2), 35-72. Retrieved from http://www.scielo.oces.mctes.pt/pdf/rpe/v23n2/ v23n2a03.pdf

Campos, M. M., Esposito, Y. L., Bhering, E., Gimenes, N., \& Abuchaim, B. (2011). A qualidade da educação infantil: Um estudo em seis capitais brasileiras. Cadernos de Pesquisa, 41(142), 20-54. doi:10.1590/S0100-15742011000100003

Delval, J. (2002). Introdução à prática do método clínico: Descobrindo o pensamento das crianças (F. Murad, Trans.). Porto Alegre, RS: Artmed.

Freitas, L. B. L., \& Shelton, T. L. (2005). Atenção à primeira infância nos EUA e no Brasil. Psicologia: Teoria e Pesquisa, 21(2), 197-205. doi:10.1590/S0102-37722005000200010

Imanishi, H. A., Passarelli, V. L. S., \& La Taille, Y. (2011). Moral no mundo adulto: A visão dos jovens sobre os adultos de hoje. Educação e Pesquisa, 37(4), 743-762. doi:10.1590/S1517-97022011000400005
La Taille, Y. (1999). Autoridade na escola. In J. G. Aquino (Org.), Autoridade e autonomia na escola: Alternativas teóricas e práticas (pp. 9-30). São Paulo, SP: Summus.

La Taille, Y. (2000). Para um estudo psicológico das virtudes morais. Educação e Pesquisa, 26(2), 109-121. doi:10.1590/S1517-97022000000200008

La Taille, Y. (2006a). A importância da generosidade no início da gênese da moralidade na criança. Psicologia: Reflexão e Crítica, 19(1), 9-17. doi:10.1590/S0102-79722006000100003

La Taille, Y. (2006b). Moral e ética: Dimensões intelectuais e afetivas. Porto Alegre, RS: Artmed.

La Taille, Y. (2009). Formação ética: Do tédio ao respeito de si. Porto Alegre, RS: Artmed.

La Taille, Y. (2010). Moral e ética: Uma leitura psicológica. Psicologia: Teoria e Pesquisa. 26(No. Esp.), 105-114. doi:10.1590/S0102-37722010000500009

La Taille, Y., Justo, J. S., \& Silva, N. P. (2010). A escola e os valores: A ação do professor. In Y. La Taille (Org.), Indisciplina/disciplina: Ética, moral e ação do professor (3rd ed., pp. 5-21). Porto Alegre, RS: Mediação.

La Taille, Y., \& Menin, M. S. S. (Orgs.). (2009). Crise de valores ou valores em crise? Porto Alegre, RS: Artmed.

Lei No. 11.274, de 06 de fevereiro de 2006. (2006, 7 de fevereiro). Altera a redação dos arts. 29, 30, 32 e 87 da Lei No. 9.394, de 20 de dezembro de 1996. Retrieved from http://www.planalto.gov.br/ccivil_03/_Ato20042006/2006/Lei/L11274.htm

Machado Junior, L. B. S. (2009). La formación del concepto de autoridad escolar en los niños en la cultura brasileña: Un ensayo sobre sus particularidades y reflejos en la convivencia democrática. Educere, 13(45), 519-522. Retrieved from http://www.scielo. org.ve/scielo.php?script=sci_arttext\&pid=S131649102009000200026\&lng=es\&nrm=iso

Martins, R. A. (1986). Intenção e consequência no julgamento moral (Unpublished master's thesis). Fundação Getúlio Vargas, Rio de Janeiro, RJ.

Ministério da Educação e do Desporto. Secretaria de Educação Fundamental. (1997). Parâmetros curriculares nacionais: Introdução aos parâmetros curriculares nacionais. Brasília, DF: MEC/SEF.

Ministério da Educação e do Desporto. Secretaria de Educação Fundamental. (1998). Referencial curricular nacional para a educação infantil. Brasília, DF: MEC/SEF.

Montenegro, T. (2005). Educação infantil: A dimensão moral da função de cuidar. Psicologia da Educação, 20, 77-101. Retrieved from http://pepsic.bvsalud.org/pdf/ psie/n20/v20a05.pdf

Muller, A., \& Alencar, H. M. (2012). Educação moral: O aprender e o ensinar sobre justiça na escola. Educação e Pesquisa, 38(2), 453-468. doi:10.1590/S1517-97022012000200012 
Paschoal, J. D., \& Machado, M. C. G. (2009). A história da educação infantil no Brasil: Avanços, retrocessos e desafios dessa modalidade educacional. Revista HISTEDBR On-line, 9(33), 78-95.

Pedro-Silva, N. (2010). Ética, (in)disciplina e relação professor-aluno. In Y. La Taille (Org.), Indisciplina/disciplina: Ética, moral e ação do professor (3rd ed., pp. 55-94). Porto Alegre, RS: Mediação.

Piaget, J. (1975). A representação do mundo na criança (A. U. Sobral, Trans.). Rio de Janeiro, RJ: Record. (Original work published 1926)

Piaget, J. (1994). O juizo moral na criança (E. Lenardon, Trans.). São Paulo, SP: Summus. (Original work published 1932)

Piaget, J. (1954). Les relations entre l'intelligence et l'affectivité dans le developpement de l'enfant. Rtrieved from http://www.fondationjeanpiaget.ch/fjp/site/textes/ VE/JP54_cours_affect.pdf

Sayão, D. T. (2010). Não basta ser mulher... não basta gostar de crianças... "Cuidado/educação" como princípio indissociável na educação infantil. Educação, 35(1), 69-84. doi:10.5902/198464441604

Tognetta, L. R. P. (2009a). A formação da personalidade ética: Estratégias de trabalho com afetividade na escola. Campinas, SP: Mercado de Letras.

Tognetta, L. R. P. (2009b). Perspectiva ética e generosidade. Campinas, SP: Mercado de Letras.

Tognetta, L. R. P., \& Vinha, T. P. (2007). Quando a escola é democrática: Um olhar sobre a prática das regras $e$ assembleias na escola. Campinas, SP: Mercado de Letras.

Tognetta, L. R. P., \& Vinha, T. P. (2009). Valores em crise: O que nos causa indignação? In Y. La Taille \& M. S. S. Menin (Orgs.), Crise de valores ou valores em crise? (pp.15-45). Porto Alegre, RS: Artmed.

Vale, L. G., \& Alencar, H. M. (2012). A generosidade em contraposição à obediência à autoridade: Juízos morais de crianças e adolescentes. In C. B. Rossetti \& A. C. Ortega (Orgs.), Cognição, afetividade e moralidade: Estudos segundo o referencial teórico de Jean Piaget (pp. 215-235). São Paulo, SP: Casa do Psicólogo.
Rosana Akemi Kawashima holds a Ph.D. in Education from Universidade Estadual Paulista "Júlio de Mesquita Filho".

Raul Aragão Martins is a Professor at the Universidade Estadual Paulista "Júlio de Mesquita Filho".

Received: Oct. 9, 2013

1st Revision: Sep. 11, 2014

2nd Revision: Dec. 11, 2014

Approved: Dec. 12, 2014

How to cite this article:

Kawashima, R. A., \& Martins, R. A. (2015). The absence of generosity and obedience to authority: Judgments of teachers and students from kindergarten. Paidéia (Ribeirão Preto), 25(60), 115-123. doi: 10.1590/1982-43272560201514 